\title{
Queer Apocalypse: Attila Richard Lukacs at the End
}

\section{ERIC SAVOY}

Eric Savoy is associate professor of English at the Université de Montréal. He has published widely in American Literature and queer theory; more recently, he is interested in what he conceptualizes as "queer formalism." This is his first foray into art criticism. His email is eric.savoy@umontreal.ca

The present study is an analysis of what painting can become in the hands of those who both fear and desire that the meaning of a painting is, always, another painting.

- Norman Bryson (xix)

His skins are now like Botticelli's St. Sebastian: beatific, but still meaning business.

- Bruce Headlam (84)

And always, in the background, was Berlin ... Already I had begun to teach myself German, by one of those learn-it-in-three-months methods. While riding on the buses, I recited irregular verbs. To me they were like those incantations in The Arabian Nights which will make you a master of a paradise of pleasures.

- Christopher Isherwood (132-33)

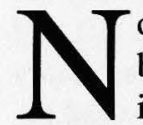

o contemporary Canadian artist is more highly acclaimed, both at home and abroad, than Attila Richard Lukacs: this is incontrovertible, but it is not news. From his first exhibition

- Prime Cuts, in 1983 - to the avid promotion of his high-realist images of soldiers and soccer boys by the Diane Farris Gallery, to the enormous 'historical' canvases produced in Berlin in the early 1990s, Lukacs has attracted the attention of audiences high and low - very high, very low. In the notes to the exhibition catalogue for Patriotism/Leadership/Disclipline, Lukacs's 1990 show organized 


\section{2 / Savoy}

by Farris, Thomas Sokolowski observes that "Yet again, Lukacs has given us a lot to think about and it's frightening as hell" (iv). Lukacs's work is "frightening" to some audiences because it analyzes, in highly formal terms, not simply the encroachment of the homoerotic into the cultural places of male power, but indeed the complete interlinearity of the homoerotic and the homosocial. This is especially true of Lukacs's Berlin canvases, a series entitled $E$-Werk. Consisting of six enormous paintings whose images richly interfuse tough male bodies at work (in the public square, in the steelworks, in the abattoir) with the fetish objects of gay culture, the collection is evidently but obliquely concerned with history, with the painter's historical moment, and with the implications of this moment for bodies, nations, sexualities, desires.

Most striking, though, is the self-absorption and self-reflexivity of Lukacs's work: his exploration of the relevance of art that comes late in time, and that knows its own lateness, strikes me as the primary query that organizes Lukacs's other historicisms. In the argument that follows, I interrogate the various ways in which Lukacs's compositional methods produce particular kinds of 'meaning': what I mean by 'meaning' is the opportunity for the viewer to recognize something about the relation between the past and the present, something that seems distinct and important. It is tempting to separate the various semiotic gestures of Lukacs's work, to argue that his gayiconic bodies are laminated onto other schemes of reference, having to do with national politics or art history. But the matrix of his painting is more complex than that. I shall attempt to demonstrate that Lukacs's work is properly understood as allegorical rather than realistic (or indeed, as straightforward 'history' or 'narrative' painting at all), and that the relation to history sustained by his best work is a refractory one, arising from the ironies of camp. We are accustomed to thinking of certain performances, or certain objects, as 'camp' in a way that combines comedy with a specifically gay approach to recycling the detritus of history and popular culture. But is it possible that camp has its entirely serious side? What might camp signify as a critical term in relation to painting that is, in several senses, monumental?

In this discourse, which will be very much concerned with the representation of endings or culminations in the work of Attila Lukacs, my point of departure is the endpoint of Globe and Mail critic John 
Bentley Mays's address that opened the exhibition of Lukacs's $E$ Werk series at the University of Calgary's Nickle Art Museum on September 22, 1995: according to Mays, Lukacs achieves "historical painting of the first importance" because it locates "Europe' in its last fin-de-siècle period," and as such constitutes "the painting of rupture." I am struck by two implications that arise from Mays's observations, both of which I view ironically. First of all, the rhetoric assigns primacy to history painting as a genre, particularly to history painting that articulates its continuity in the grand tradition rather paradoxically, in the semiotics of rupture. This provides a vantage point on the uses of 'art history' for the ends, and endings, of the postmodern that is rich in conceptual potential, and which I shall take up in due course. Secondly, Mays's attempt to locate the 'meaning' of Lukacs's $E$-Werk ironically elides the matter of painting in 'history painting.' It tends - and intends - to look through representation, as though painting were a transparent record of historical sensibility. This rather naïve will-to-transparency limits the ground and meaning of visual art solely to its political engagements, or to its social realism at a momentous turn in recent history, perhaps indeed the brink of secular apocalypse. Under such an ideology of art, the painter's role is to articulate the melancholia associated with end-times, not least with the seemingly last fin of Europe's long tradition of fins-de-siècle. In privileging the referent over the sign, Mays's observations are characteristic of an arthistorical discourse that I shall call the tactics of postponement, by which any explanation of the semiotics of painting is deferred through a tactics of referral to the historical thematics of the work. Mays's tendentious conclusion that "the rupture is in ourselves" begs a return to the work of Lukacs's $E$-Werk, its economy of signs.

In what follows, I diverge rather sharply from a particular kind of art criticism that attempts to purchase mainstream approval (or at least tolerance) for aggressive, shocking, or bewildering painting by purporting to explain its 'urgent social message.' If I have little to say about the reunited Germany, and even less about the fearful fascination of skinhead culture that confirms a prior narrative, ideologically necessary in North America, about what we have always 'known' about German nihilism, then my silence arises from my conviction that Lukacs's painting is not properly understood as directly and transparently historical. Its historicism is allegorical 


\section{4 / Savoy}

rather than realistic, and the referent of Lukacs's allegorical narratives is, broadly speaking, desire: desire, that most recessive object of representation, is in some sense always what allegory is about, for first and foremost it encodes in its obscure signs the uneasiness it prompts in the reader or viewer - the desire to interpret, to master this evasive representation, to know. This hermeneutic desire is not, I suggest, fundamentally different from the highly conflicted eros that strikes us - first, violently, unforgettably - in this series of canvases, with their diverse images of male beauty that hover tensely between the homoerotic look they invite and the homophobic abjection of that look. Both erotically and interpretively, the immediate function of Lukacs's work is to disorient the viewer, to leave us wondering where we are in the realm of visual culture, and to disable any quick or instinctive recourse to a convenient semiotic template.

This is not to suggest that the allegorical mode of Lukacs's work is ahistorical, but that in Lukacs's most complex and memorable work, he sustains (I hesitate to say 'represents') a particular mode of desire, routed and relayed through a circuit of highly connotative images, that constitutes his relationship with the history of painting. Yet such images are highly dissonant in their allusive gestures: Lukacs ransacks and plunders the historical archive, treats classic painting with irony, yet seizes upon it with an odd kind of tenderness as well. His relation with the history of the medium is too playful and capricious to be called 'iconoclastic,' for Lukacs is a breaker of images only as part of the contract of borrowing, appropriating, and recirculating; it is perhaps an ironic iconism, a queer ${ }^{1}$ relation that may be understood as reconstituting the visual field of that painting. Yet, art history itself is neither an ultimate referent nor a self-contained object of

1 "Queer" is the most overused adjective in recent gender studies scholarship; its circulation in a wide range of contexts has blunted its critical edge. In the field of academic criticism, I understand "queer" to signify a formalist attention to all modes of cultural representation - a curiosity about how textual, visual, filmic media communicate - that is informed by the artist's aberrant relation to traditional artistic conventions and heteronormative sexualities. I am guided by Ellis Hanson's observation that "in the past decade, queer theory, the deconstruction of sexual rhetoric, has revolutionized the field simply by conceiving sexuality as a story we tell about ourselves, a story that changes with every telling, that is written as much by the audience as by the ostensible author" (2072, my emphasis). 
representation: rather, it provides a body of signs - and a rich lexicon of signs of the body - that is cited connotatively rather than directly, and deployed for revisionist purposes. As such, prior painting becomes not a gestural end, but a place of beginning, a site of overwriting. The connotative play of art historical allusions in Lukacs's work permits a figurative moment - a turn, a troping - of the historical source. Such appropriations are pulled into the spiral of allegory by Lukacs's queer deployment of, his work upon, the borrowed image, which becomes a site at which the history of that image - the visual economy in which it has been received - is revised, reconfigured.

Allegory is a queer mode of narrative in that it can never say directly that which it sets out to demonstrate obliquely; it vehemently resists being read at the first degree, at the level of the denotative. Lukacs's narratives allegorize a belated intervention in the economy of the gaze, a revisionist desire to read 'desire' in the field of pictorial representation. Therefore, as representations of representation motivated by the desire to reconfigure desire - they focus on, and cite, images of the male body that are simultaneously redeployed for a homoerotic gaze in the present and shown to be, in their long history, always already implicated in that gaze. This is precisely the cultural field in which multiple meanings of queerness intersect: to look back with homoerotic desire is simply queer, but to set up a circuitous remapping of art history - that is, to historicize the future of the painter's moment - is a complexly queer intervention in the coherences to which art history has been made to conform. Given the long association of homoerotic desire with end times (Burton's version of the fall of the Roman Empire, Oscar Wilde's personification of the fin-de-siècle, AIDS and the apocalyptic 'end' of gay culture), as well as the various senses of ending in which Lukacs situates himself, his retrospective embodiment of queer desires - erotic, painterly, political, historical - constitute a definitive moment in the postmodern that I call "queer apocalypse."

The circuit of desire that I understand as operating in Lukacs's

${ }^{2}$ My use of this term, and indeed my entire project, is deeply indebted to Richard Dellamora's lucid mapping of apocalyptic discourses in a range of cultural fields in Apocalyptic Overtures. Dellamora argues that, in cases where a narrative of group history is blocked or occluded by the overwhelming nature of present circumstance, 


\section{6/ Savoy}

work can be clarified, perhaps, by exploring the resonances, the overlaps, among the epigraphs that I have chosen for this essay. Norman Bryson's insistence that "the meaning of a painting is, always, another painting" (xix) outlines a hermeneutic that is generally useful, though it requires some qualification: Bryson seems to suggest that the later work is oddly evacuated, that it serves as a sort of translucent screen whose function is to gesture toward its antecedent, where the plenitude of meaning will be located. I argue that in Lukacs's work, the allusive gesture is an ironically playful performative; it is less a path of affiliation - by which the later painter works under the sign of the former - than a queer appropriation, by which the later painter works over the borrowed sign. To revise Bryson, then, the historical antecedent provides neither a coherent meaning nor the ground of coherence as such, but rather a field in which meaning is contingent and coalesces uneasily in the tension between repetition and difference.

The critical problem, it seems to me, is to conceptualize the particular dynamics of this ironic performative, this play of tension at work in citation. This problem has a long history in modernism. Walter Pater, for example, who like Henry James and Gustave Flaubert refocused criticism on questions of aesthetics rather than 'content,' crudely conceived, insisted upon a transhistorical sensibility between antiquity and the Renaissance in a discourse that is poetic rather than expository: "in the subordination of mere subject to pictorial design, [Giorgione] is typical of that aspiration of all the arts towards music ... towards the perfect identification of matter and form" (111). I would argue that, for the postmodern, art aspires to the condition not of music, but of language. In other words, painting in postmodernity embodies not a fluid or transparent relation between the sign and the referent, what an earlier formalism imagined as "the condition of music," but rather the gaps and fissures that problematize the work of signification and may be said to shape a tactics of dislocation.

the "resistance to narrative coherence impels an attempt to return through art to an earlier history, which, if recovered, promises to explain and thereby remedy the inadequacies of identity and consciousness in the present" (1). If the apocalyptic approach to structuring time is "analytic," it is also, he insists, "affirmative" (26). Apocalypse is a thoroughly ironic, protodeconstructive approach to the temporality of the subject, for "to speak of historicizing the future is to speak of apocalypse" (31). 
Christopher Isherwood's account of his fascination with 'Berlin' is presented as a problem of language that places the individual on the margins of a culture, outside belonging, in an ironic space between obsure signs and impossible referents (very much like Lukacs, who tells Bruce Headlam of his move to Berlin with only "Hogan's Heroes German" [84]). The textures of this difficult language, Isherwood claims, "were like those incantations in The Arabian Nights which will make you a master of a paradise of pleasures" (133). The seduction of the other is a linguistic eroticism, predicated on alienation. But whereas Isherwood's double metaphor (the sounds of the German language as erotic incantation or spell, the erotic itself as Orientalist) seems highly attenuated, Lukacs's eroticism seems strikingly punctual. My concern, however, is not with the bodies imaged in his work as much as with their provenance, their painterly language. If 'Berlin' may be understood as signifying for Lukacs a place of proximity to the art historical, then the desire for mastery over "a paradise of pleasures" required the taking-up of another grammar, a painterly language, a semiotic field in which he would remain paradoxically outside while appropriating its signs for his own uses. His work is to queer those signs in a composition whose value inheres precisely in their lack of fluency, in their stumbling, hesitating gestures. Isherwood speaks of reciting "irregular verbs"; I see Lukacs's queer historical language as a will-to-the-irregular, ${ }^{3}$ a fracturing of the coherences of the transitives in art history.

More precisely, I understand Lukacs's play with art history as deploying the performative of camp. Notoriously difficult to define, camp is a matrix of gestures that is resolutely queer, both in its historical association with gay men and in its double-talk of parodic or ironic allusion. It signifies, but it also signifies $u_{p o n}{ }^{4}$ the historical

${ }^{3}$ As John Plews observed in reading this essay, what is so curious about irregular verbs is that they are often the most frequently used verbs. That is how we remember their irregularity. This irony has its resonance with artistic parody in general, and with Lukacs's painterly 'grammar' in particular: his appropriated images tend to be familiar, and his reproduction of them tends to emphasize their sexual 'irregularity' and thus to fracture their 'regular' iconic status.

4 "To signify upon" is both to play a trick upon and to announce the trick in a sassy way. The term comes from African-American popular culture, but has its resonances in gay culture, as I demonstrate in my article about Bugs Bunny and gender insubordination, "The Signifying Rabbit." 


\section{8/ Savoy}

residue that it redeploys; it locates meaning usually in the incongruous relation, the tension, between the reference or antecedent, and the present conditions in which the antecedent is invoked. Camp - like all forms of irony - is a supremely knowing performative, and what it knows is its own power to disrupt the coherence of the icon, the gender, the often ineffable 'thing' with which it plays. A camp utterance never brings forward the past object, or the Other, as meaningful in itself, but rather as a field in which the connotative properties of the object may be dispersed and appropriated for revisionist reading of the past, or for ironic insight into the conditions of the present. ${ }^{5}$

It is helpful to approach Lukacs's sophisticated and often tortuous deployment of the tactics of camp by way of analogy, an illustrative example in another medium that will, I hope, frame the ironic uses of the past at work in the queer postmodern. This analogy arises from my conviction that, as subjects of visuality, we are more skilled at recognizing camp in film - a medium that supplements the visual field with the linguistic performance - than in what we are inclined to understand as the static opacity of painting. There exists a profound affinity between the ways in which Attila Lukacs and Derek Jarman construct themselves as artists and inscribe themselves into the field of the postmodern through a queer apprehension of the connotative uses of the artistic icons in the historical field. Jarman's Caravaggio, released in 1986, narrates the painter's studio practice: his erotic relations with the models who became, on canvas, his St. Matthew and John the Baptist, and his dealings with the Vatican officials who commissioned the work and whose own homoeroticism

${ }^{5}$ Camp, like apocalypse, is a particular and highly ritualistic approach to history, the uses of the historical artifact, and the temporality of subject-object relations. Moe Meyers shrewdly defines camp as "the homosexual gestuary" that "unwrites the ontological basis of dominance (the heterosexual imperative)," that serves as a marker for "the queer subject's uncanny experience of the impossibility of representing his/ her desire within the parameters [of dominant culture]" (18-19, second emphasis mine). I am struck by Meyer's description of the camp performative as uncanny: if the uncanny refers to that which was once familiar but has been repressed, only to emerge belatedly in the shock of recognition, then Lukacs's pictorial citations go well beyond conventional notions of parody. Indeed, the 'Lukacs effect' might be understood as a transfiguration of the cited/sighted object, the historical referent, by which we grasp its meaning for the first time. 
accommodated the deployment of beautiful bodies for the ideological work of the Counter-Reformation. The film is less a biography of the painter's Roman period in the early seventeenth century than an experimentally and politically queer revision of desire in the production and reception of art, in which the powerful attractions of violence, masochism, and abjection are situated in the look that generates, and is represented within, religious painting. The high sacred, the film explains, arises from "a conspiracy between church and gutter," and it is precisely this ironic fusion of the erotic with the sacred that permits Jarman's play with camp. My object of scrutiny here is not the biographical resemblances among Caravaggio, Jarman, and Lukacs as much as it is the affinities of sensibility that are realized in the campy deployment of art historical sources. To put the matter another way, why does their work look alike, apart from their collective preference for the color black?

Framed by the spectacle of the dying artist attended by his mute assistant, Jerusaleme, Caravaggio is organized as a series of flashbacks. The narrative point of view arises from Caravaggio's position within the nexus of artistic production, power, money, and sexuality: eschewing any romantic construction of the interlinearity of homoerotic desire and artistic genius, Jarman shows how the Church pays the artist and the artist pays the models. As Michael O'Pray suggests, only Caravaggio's acts of painting carry any narrative impact, for "around him swirls the history of the final years of the Italian Renaissance and he stands at its still centre, in the eye of the storm which is the darkness of his studio" (151). Yet the film is attentive to the cultural circuits by which bodies are requisitioned for the game of power: Caravaggio's paintings - despite, or perhaps because of their sensuality - are part of the Catholic Church's apparatus for disciplining the faithful, but these bodies emerge from and return to the underclass as objects of representational and literal eros, remaining quite remote from the regime that has drafted them so fleetingly.

Jarman's exposure of the hypocrisy that sustains repressive institutions like the Catholic Church depends upon his juxtaposition of dissonant images and highly incongruent desires and motives. In what is perhaps the most brilliant scenic example of this compositional matrix, a minor official named Giovanne Baglione - who has sneered and minced his way through the film - sits in a bathtub and composes 


\section{0 / Savoy}

a vitriolic attack on the painter on a 1920s-era Royal typewriter (Figure 1). Leo Bersani and Ulysse Dutoit describe the scene as one of "comic relief" (37), but the full implications of camp will emerge from an analysis of the relation between Baglione's discourse and visual image. Baglione reads what he has just typed:

"...with the support of [revises: 'with the connivance of'] his Cardinal, this second Michelangelo stole the commission for the paintings of St. Matthew: a conspiracy between church and gutter." Good! "Those who love art must be alerted to the poison which seeps into the body of our Renaissance like a pernicious drug. The shadows which permeate his paintings are no less insidious than those which cloak his ignorance and depravity." Hmm... [begins to type again] "a ... sad ... reflection ... of ... our ... TIME ..." [Baglione falls back from the typewriter.]

A cluster of specific images - the subject in the bathtub, the bathtub itself as a scene of vituperative and vitriolic writing, the pallor of Baglione's skin, the odd turban on his head - gesture emphatically to David's Marat Assassiné (Figure 2), and in so doing may be

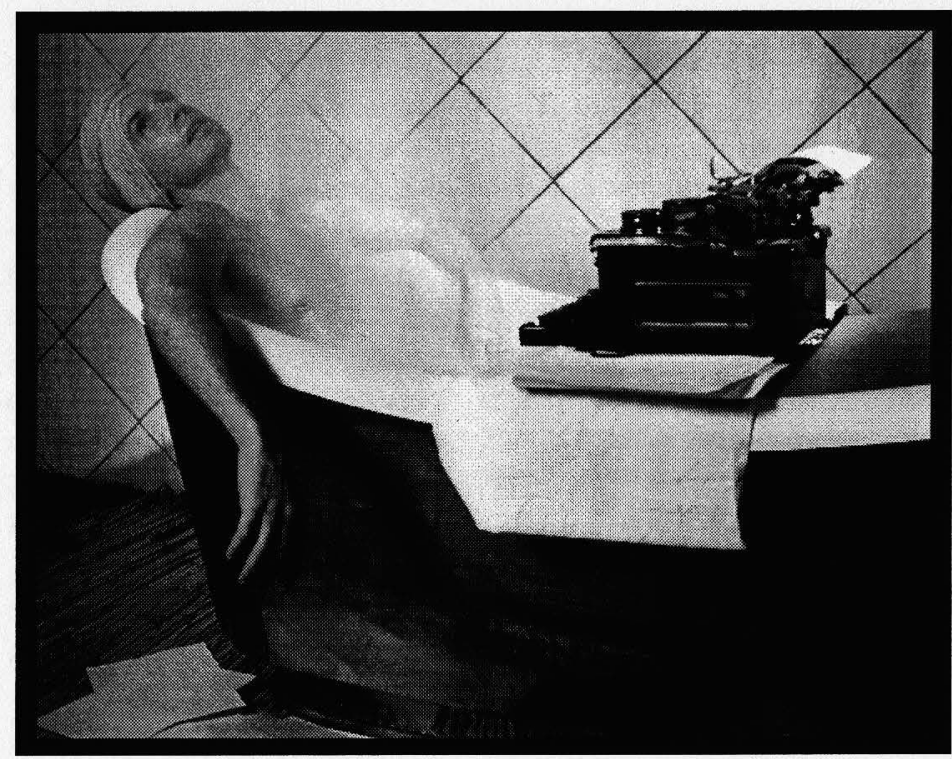

Figure 1: Still from Derek Jarman's Caravaggio, courtesy of the British Film Institute. 


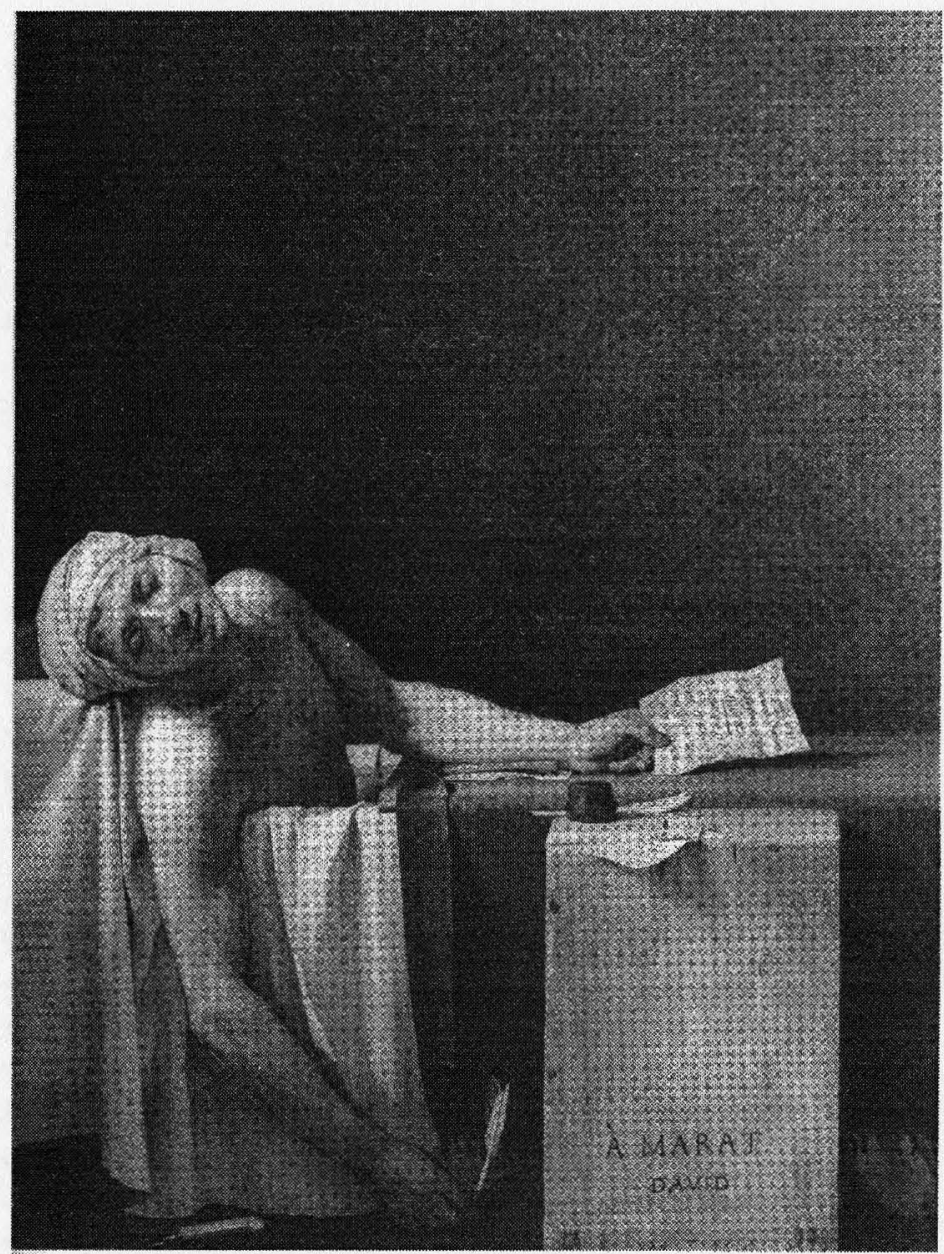

Figure 2: Jacques-Louis David, Marat Assassinated, Musées royaux des Deaux-Arts, Brussels.

understood to engage in an entirely camp relationship with that painting and its historical moment. It is an ironic moment in the film's narrative that signifies in multiple directions. Questions of parody are usually framed in terms of whether the later work intends homage or burlesque, that is, whether the work is a reverential affiliation or a satire. Such an approach will not help us here, because Jarman's invocation of David queers the dynamics of parody itself 


\section{2 / Savoy}

precisely through the performative of camp allusion to iconic objects. At one level, the filmic moment works like really bad drag: the viewer is invited to bring forward David's gaze upon the spectacle of noble self-sacrifice in the service of the state, which clarifies Baglione's pettiness through the incongruity of the juxtaposition; in this way, the cleric 'becomes' the bad copy of an original to which he can never aspire. Yet, the circuits of parody extend in a kind of reverse discourse back to David's subject, to undermine the nobility of that subject. When situated within, and not against Jarman's spectacle, Marat - who was simultaneously l'ami du peuple and the very embodiment of the Terror - is seen as essentially like the smallminded, hypocritical, and jealous Baglione in the Vatican, and by implication, both David's reverential gaze and the politics of iconmaking are called into question.

My point is that the queerness of Jarman's camp gesture accrues precisely in its ability to signify upon, and thus to disrupt the coherence of, the narratives of masculine desire that are vested with nobility by the official discourses of the state. The point of camp is less comic than ironic: it invites not so much the lucidity of laughter as the casting of a shadow upon the prior icon, which becomes not a site of meaning, but a site in which received meaning is to be problematized. Moreover, the queerness of such a political deployment of camp depends crucially upon the draglike, the cross-dressing, strategy of the cluster of specific images that can only connote the prior painting and its historical circumstances. Therefore, these fragmentary or synecdochic images open the space not only of resemblance to earlier painting, but to radically different historical moments, narratives, and political agendas: Jarman's narrative is not David's narrative; there is no Charlotte Corday to dash in and murder the nasty Baglione. The point of camp is not repetition, but to show the seams between the iconic moments, and it is the seams, perhaps, that convey the seamy. It is this disconcerting use of the connotative sign in the camp performative, I suggest, that not only consolidates the ironic relation to the past image and its attendant ideology, but that also pulls the postmodern into an allegorical mode of discourse rather than a mere parody, a mere repetition. By "allegorical mode," I mean the deployment of a sign (in this case, David's painting) that cannot be read at the first degree of signification, that compels recognition, but not in a simple or direct way; consequently, the 'quotation' of the 
painting opens the challenge of interpretation-a kind of hermeneutic puzzle - the burden of which is to integrate the visual image into Jarman's narrative point. It is by no means straightforward. The shift into allegory marks, and constitutes, the shift into a register of the sign - a politics of evocation - that queers as it queries. And as allegory, this discourse of Jarman's - which I see as entirely typical of the queer postmodern - embraces a confluence of shadows whose articulation remains oblique, a matter of gesture.

In his 1993 article for Saturday Night on the 'real' Attila Lukacs, Bruce Headlam sustains art historical comparisons not, as I have done, at the level of the sign, but rather at what he understands (correctly, I presume) as the level of the referent. "Caravaggio," he writes, "dragged his haloed saints back into the shadowy Italian streets he knew. Lukacs plucks his sweet and tender hooligans off the corners and out of the basement thrash-bars and puts them on the stage of high tragedy" (84). While I am uncomfortable with this will-totransparency - this strategy of locating the 'real' referent in the desires that motivate the painter's compositional process - I admire the knowledge effect generated by Headlam's juxtaposition: I can no longer see Caravaggio's work except through the frame of artistic production like Jarman's and Lukacs's, and vice versa. This too is an aspect of the shifts in perception facilitated by the uses of camp, insofar as the juxtaposition intervenes in the linear, chronological narratives that constitute the academic discipline of art history to suspend not only the question of priority, but also the site of authenticity.

It is tempting to refer questions of authenticity to fictions of intentionality; however, just as the meaning of Jarman's scene lies in the allegorical circuits, the connotative play of the sign, that invoke David without deferring to his work, so too the real Attila Lukacs by which Headlam means the biographical fiction - is inseparable from his discursive performances, nearly all of which contest the real through the incongruities of camp. His observations are an odd fusion of glamourina and garbage: he told Saturday Night (perhaps alluding to Jarman) that his paintings "raise [skinheads] out of the gutter," but his next comment - "buy 'em a case of beer, and they're yours" (84) - deconstructs the transcendent moment. The English word "camp" comes, I think, from the French verb se camper meaning 


\section{4 / Savoy}

"to take a stand," with the connotation of "to pose"; Lukacs's mastery of striking a pose simultaneously titillates and horrifies his audience, while the rapid shifts of pose are a queer dislocation of 'authentic' subjectivity. There is, for example, the effeminate autobiographical pose of 'Ricky,' his childhood nickname: 'My younger brother used to play hockey, and my older brother used to work out at my dad's hobby ranch. I stayed at home and did needlepoint" (57). Ricky approaches the ironic Attila in the narrative of his summer job as a window-dresser at The Bay: "The big blow-up came when I was supposed to do this set of ladies' fashion windows, and they wanted ethnic ... I started cutting clothes up, destroying thousands of dollars of merchandise. They freaked. Their idea of ethnic was Eskimo" (58). And later in Berlin, Attila, the analyst of media culture, makes ironic use of the 'Ricky' pose: "Married with Children may be garbage in English, but dubbed into German it's brilliant" (84). Perhaps most intriguingly, Lukacs's discourses on his own artistic production seem to begin in one voice but to slide, almost imperceptibly, into another voice that unsettles, comments ironically upon, the pose of the first. For instance, he explains the art of National Socialism, his primary field of play in the $E$-Werk series, as follows: "even though it was controlled by governments that were actually very homophobic, there's a lot of elements within it that give it a very homoerotic although I hate that word - homoerotic kind of ... well, you know." This is used to set up his last word on the subject of sources: "They don't all have to be skinheads, you know," he claims irately; "Did it ever occur to anybody that I may simply have trouble drawing hair?" (87). It seems to me that the end of Lukacs's posing, the camp effect of his rhetoric, is a fairly conclusive rupture in the discursive performances and the categories of knowledge that organize conventional art criticism. Here, his slide from one voice into another deconstructs not only the academic tendency to locate desire in intention, but also the illusion that the 'authentic,' the 'real,' is locatable anywhere outside the circuitous play of discursive signs. ${ }^{6}$ This, I suggest, is the discourse of the end, the queer apocalyptic.

II am not the first critic to argue that Lukacs's representations might be read as camp. Piet Defraeye suggests that "Lukacs flirts with Nazi and fascist propaganda imagery ... but his Teutonic imagery often borders on camp" (424). Defraeye does not pursue the subject, perhaps because his project is not concerned with the historical 
This deconstructive potential of camp is precisely what I want to bring forward as a conceptual frame in which to approach Lukacs's painting. Lukacs's delight in the collision of incongruous poses has its painterly qualities as well as its discursive ones: like his enunciations, his painting, particularly when it moves into allegory, distances and problematizes questions of reference and intent. The effect of camp's appropriation of 'art history' is to diffuse the language of the look, the visual field in which we are 'taught' to view the history of painting as a linear, progressive narrative.

It should by now be obvious that my propositions about the queer postmodern, the apocalyptic moment, depend upon the fairly precise location of ironized retrospection in the exchange of looks that I understand as enacted within a painting. In situating Lukacs's work within this paradigm, I am struck by his rapid development, by both the continuities and the complex shifts in his deployment of allegory between the work of his early maturity and his $E$-Werk series. To provide an example of the former, I want to glance at his 1988 painting, The Young Spartans Challenge the Boys to Fight (Figure 3), owned by the London Regional Art and Historical Museum. Here, it is tempting to read the painting as achieving allegory through the superimposition of one plane (the bodies) upon another (the red wall of Stalinist work symbols), by which the background would provide a semiotic toolkit that pushes the foreground narrative toward the historical referent. Such a reading might conclude that the painting is about the political collision between the Soviet empire and the imperatives of German reunification. As such, it is guided by the episteme of historical painting that resolves the work into a simple syntax of narrative and a coherent political binary opposition, both

register in which camp finds its ludic ironies. Defraeye understands Lukacs's canvases as bodies in performance, and not surprisingly, his overarching critical metaphor is that of "Lukacs's theater" (422). Both theater and camp as critical terms impose a temporal dimension on the signifying gestures of spatial art like painting, but theater, at least in Defraeye's work, limits Lukacs's frame of reference to contemporary gay culture and thus understands 'performance' along one temporal axis only, and that axis is horizontal, not retrospectively vertical. "We know these people on the canvas" (422), he claims; "Lukacs's gym bodies are part of a fashion-stimulated, code-driven culture of simulation and imitation ... [his] figures look like butch clones" (425). I take Defraeye's point, but I suggest that the practices in visual culture by which "we know these people" are considerably more complex. 


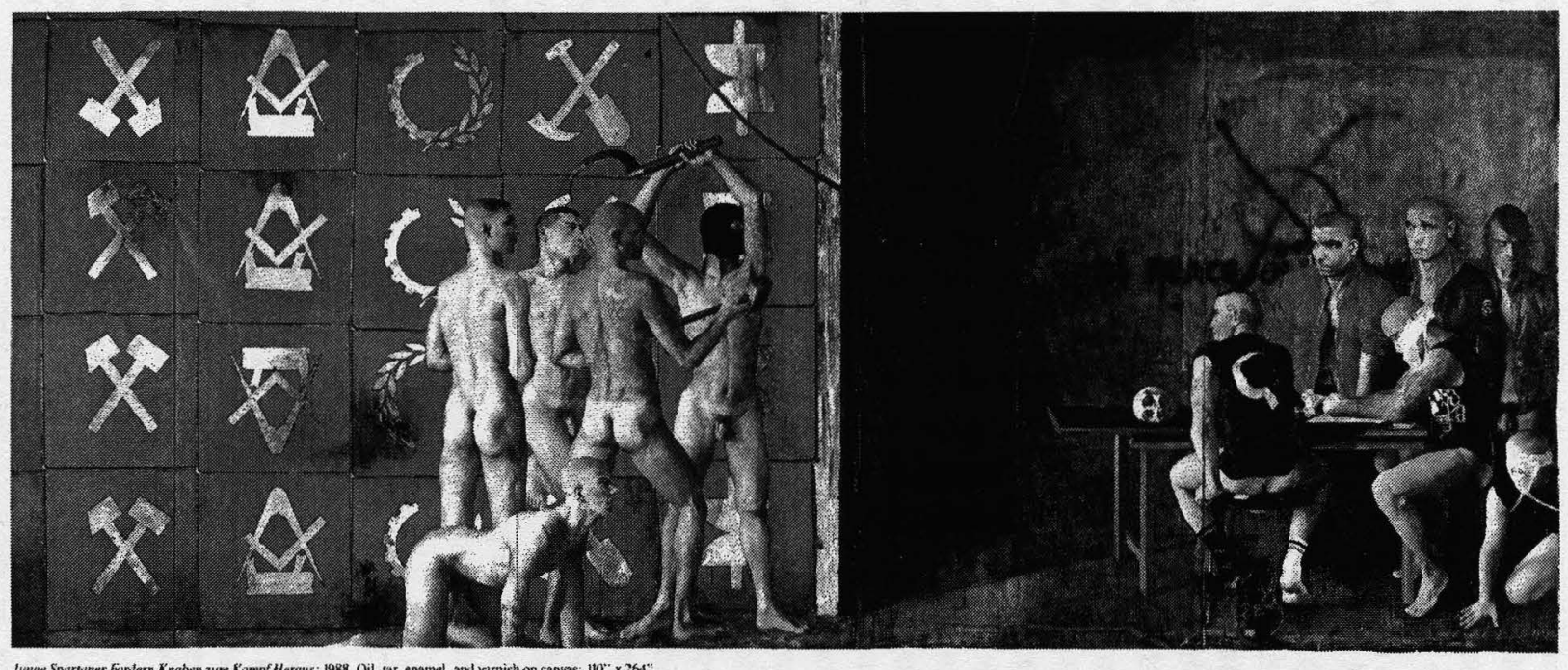

Figure 3: Attila Richard Lukacs, The Young Spartans Challenge the boys to Fight, London Regional Art and Historical Museums, London, Canada. 
of which require reading from the old 'left' to the new 'right.' Yet, this hermeneutic, while not at all incorrect, aspires to a clarity - a merging into the historically real - that the play of allusion will problematize through ironic retrospection.

The temporal linearity of a simplistic left-to-right allegorical reading is reversed by the circuits of Lukacs's retrospective look: the figures on the left strike a pose that is borrowed from Degas's Young Spartans Exercising of 1863. In Degas's painting, the look is the address of a challenge between the women and the boys; Lukacs's use of the source involves a turning-around of the figures away from the heterosocial toward the homosocial, as well as a turning of the look in a defiant gesture toward political adversaries within the male homosocial continuum. This ironic 'turning' has important implications for the ways in which Lukacs imagines the past to gesture toward the present, which I shall take up shortly. The figures on the right are grouped according to Caravaggio's The Calling of Saint Matthew, and participate in Caravaggio's representation of the abjection that in itself is spiritually transcendent, a condition of knowing. Lukacs brings forward too the signs of the game, which Headlam describes as "a card game of humiliation, a kind of sadomasochistic strip-poker" (86). At one level, the juxtaposition of icons from the past corroborates the political allegory that I outlined above, in the collision between the purity of socialist masculinity and the dangerous erotic play, the squalid fascination, of the new queer right. However, Lukacs's ironic retrospection - his queer version of 'back to the future' - dislocates the meaning of Degas and Caravaggio by the camp appropriation into allegory, the incongruity between the somatic or spiritual calls to purity in the historical sources and the erotic economy of the present. It also allegorizes allegorical painting itself in the field of the look that is exchanged between right and left. By this manoeuver, the allegorical spirals cannot be contained by a referential reading that gestures only to recent political events in eastern Europe. ${ }^{7}$ Rather, the fearful fascination that shapes the look

TPrevious attention to this painting's allegorical dimension tends to interpret allegory either too literally or too fancifully. As an example of the former, Ken Johnson writes in Art in America that "there's something compelling abut Lukacs's allegory of the notion that conflict between nations is driven by a primal, masculine urge for combat" (204). As an example of the latter, Mays suggests that "the skinheads become 


\section{$18 /$ Savoy}

between the groups on the canvas is framed by Lukacs's ironic look at the history of figure painting: and the point of that look, and the point of the allegory, is the demonstration of the homoerotic that invests, and may be understood to constitute, the great icons of the homosocial.

This ironic reconfiguration of history to produce what might be called the contemporary past depends upon troping the antecedent paintings within the dislocations of queerly postmodern camp. Finally, the multiple narratives, the multiple interventions in the economy of the gaze engineered by Lukacs, exceed any single story, any single referent. And the resonance among these critical fictions - themselves demonstrations of the basic deconstructive tenet that any text is the allegory of its own reading - achieves a precisely queer dislocation, a complex politicization of the erotic, and an eroticization of the political. I intend this analysis of Lukacs's queer turn toward the historical as a supplement to Norman Bryson'sconception of the uses of citation as a paradoxical disruption within the logic of continuity. Lukacs, to borrow Bryson's terms from another context, "is not simply continuing a tradition. Normal analysis of sources cannot easily penetrate this subtle terrain, for in its attachment to the idea that a source is simply a block of imagery transported from image $\mathrm{x}$ into image $\mathrm{y}$, it is unable to comprehend the deployment of sources where there is no clear image $y$, and where the painter's work on sources has been carried out in terms of configuration, rather than straight importation" (37). Building on Bryson's conceptual platform, I argue, using his words, that The Young Spartans "is essentially a patterning, a re-ordering, a turning of sources; and perhaps the most accurate word to describe this activity is the rhetorical term trope, from the Greek tropos, to turn" (37).

*

I turn now to Lukacs's $E$-Werk: if the six enormous canvases of this series constitute a narrative, it is surely a highly fragmented and

allegorical figures in a much broader spiritual drama of modernity itself, in which we all are implicated" (Skinhead Paintings), and again, that both Caravaggio and Lukacs "depict events that are easily read as allegories for art's call to both play and devotion" (Male Body). I quote these examples not to argue that they are in any sense misdirected: such latitude of interpretation is precisely the attraction - and the trap! - of allegorical reading, dangers from which I am hardly immune. 

opportunities for understanding Lukacs's queer troping of historical sources, and as such, it becomes a site from which to work outward to the others. I mentioned earlier the shift toward greater complexity in Lukacs's deployment of sources within an allegorical register from a work like The Young Spartans to the work of his maturity. By greater complexity, I mean that, despite the sophisticated turning and resituation of the borrowed image in The Young Spartans, the citations retain a striking recognizability, even a kind of transparency; we know right away that we are 'seeing' Degas and Carravagio through the postmodern frame. It is this call to immediate recognition, and its attendant recall, that makes Lukacs's ironies available. But the arthistorical allusions in Glamour Crew are closer, I think, to the connotative play with parts of the image, a kind of queer synecdoche, that I demonstrated in Jarman's cinematography. The trio of male figures in the center of the painting constitutes not only the compositional point of focalization, but also the clearest site of the retrospective look, the place in which queer historicity is grounded: these figures recall, though only connotatively, David's The Oath of the Horatii (Figure 5).

Like Jarman's invocation of David's Marat Assassiné, Lukacs's point is not that his narrative will coincide with that of the Horatii, but rather will redeploy its signs and, in so doing, provide a revisionist supplement - an ironic commentary upon the ideologies of gender along the seam of its overlap. This is still an essentially camp negotation with the historical antecedent, but the queerness of Lukacs's image turns toward camp's shadowy underside, its tragic potentiality. David's Oath - perhaps the best-known example of French neoclassicism and, as Anita Brookner points out, a preRevolutionary republican manifesto (69) - narrates the interpellation of the patriarchal subject within the painting's specific story of the dedication of the male body to the nation-state. The painting's historical referent is a dispute between the rival states of Rome and Alba in the fifth century BC, a dispute that would be settled by a battle between the Roman Horatii and the Alban Curiatii. However, one of the Curatii was betrothed to Camilla, sister to the Horatii (David's woman in white). The battle was won by the Horatii; when the oldest brother announced the victory his sister Camilla cursed him for the loss of her lover, whereupon he drew his sword and killed her. The drama, in short, is one of conflict between love and violence 
Queer Apocalypse / 21

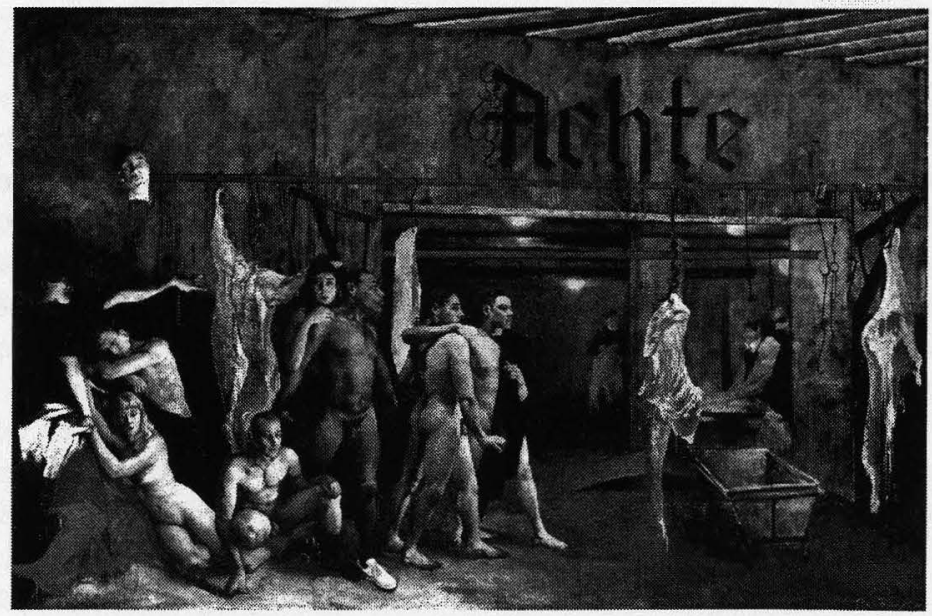

Figure 4: Attila Richard Lukacs, Glamour Crew, artist's collection.

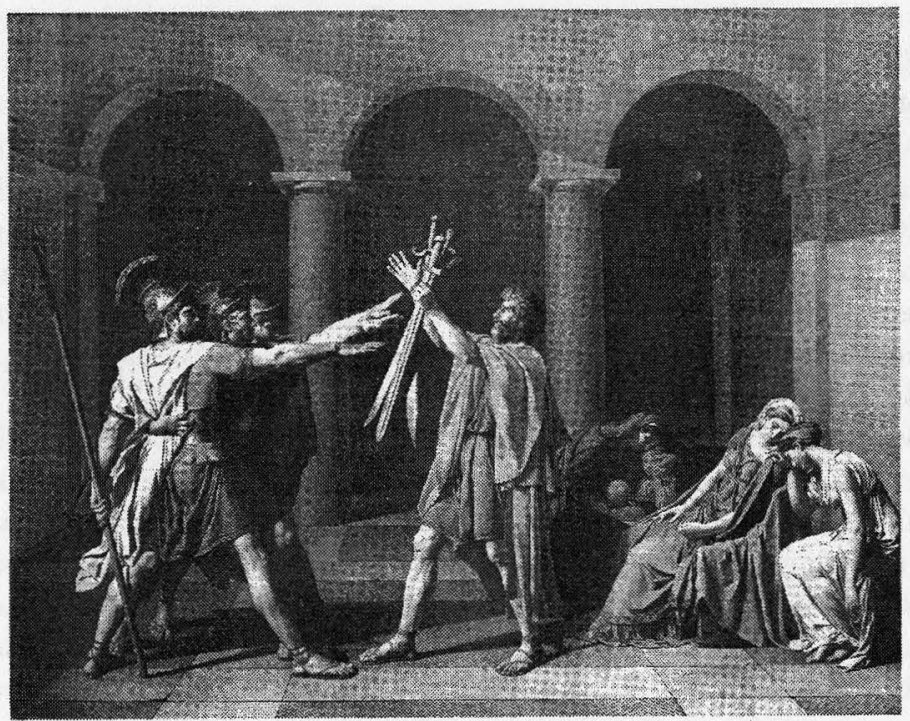

Figure 5: Jacques-Louis Davide, Oath of the Horatii, Musée du Louvre. 


\section{2 / Savoy}

of nationalist masculinities. According to Bryson, David's painting "traces the negative consequences of the subject's insertion into language and gender, for the visuality of the males is dominated by the outward projection of heroically gendered self-imagery" (71); moreover, in a circuit of substitutions, the oath of national allegiance becomes embodied in the sword, itself a sign of the father who administers and bestows. If national masculinity is an epidemic of substitutions, then the men cannot halt the ideological processes of heroic projection and destructive substitution, while the women do not speak, but themselves are signs, outside the register of speech.

In one dimension of Lukacs's painting, I would argue that he plays with the temporality of the narrative: he cites the Davidian moment through the connotative reach of the male trio, yet he brings it further along the temporal continuum and redeploys David's figures. The women become bearers of the look, their oblique glances directed beyond the frame of the narrative moments toward something - some tragic consequence? some historical event? - that eludes the gaze of the men and marks their ironic distance from the central trio. Yet Glamour Crew deploys other semiotic registers as well, registers that - unlike the layered planes of The Young Spartans - are not detachable. The images of meat I see as self-referential gestures to the beginnings of Lukacs's career: while still a student at the Emily Carr College of Art and Design, he mounted an installation of a butcher shop, with such images as a world map reconfigured as cuts of meat, under such titles as “How Do You Know You're Not Already Dead?" The setting hovers uneasily between terror and desire: if, on the one hand, it is reminiscent of 1980 s gay cruising in the meat-packing district of New York's west side, on the other, it invokes the concentration camp. Both referents are suspended under the sign of "Achte." Oddly, I find that I can go no further with this painting; I do not feel the pull toward the loquacious that I experienced with The Young Spartans. Yet I cling tenaciously to the connotative play with David's Oath as grounding the allegorical import of this narrative; and despite the murkiness of Lukacs's signs, I read the allegory as an allegory of reading: a reaching-back to David's revolutionary moment, and further back to republican Rome, and then back in turn to the future (represented in the next canvas, perhaps - that is, in the desolation of Everybody Wants the Same Thing), which is imagined negatively, in apocalyptic terms. Lukacs is unwilling to separate the destructiveness 
of violence from its erotic power. This is surely the essential point of his queer formalism. And yet this painting suggests, through its connotative play with David, both the ironies that attend that unwillingness, and the possibility of a homoerotics that refuses investment in national masculinities.

And it is precisely from this political ground that I can move forward and backward in the series. To move forward, to the depopulated world of Everybody Wants the Same Thing (Figure 6), is to encounter the end, to look it in its single face. To move backward is, ironically, to carry forward what Lukacs learned in the atelier of David: the ideologies of gender that mobilize male-male libidinal energies in the service of the nation-state. The sequence of paintings - In My Father's House, This Town, Tomorrow and Tomorrow and Tomorrow - are not, as I suggested at the outset, fundamentally 'about' Germany under reunification or the skinheads who provide the most persistently disturbing image of what we 'know' about German xenophobia. These are occasions or bodies whose banal uniformity permits their installation in a spectacle that pulls away from historical particularity toward an overarching historicity, the detached, ironical field of allegory. All three of these paintings explore not so much the implication of the homosocial in the homoerotic - the hard fact of the always already queer - but rather the ways in which male

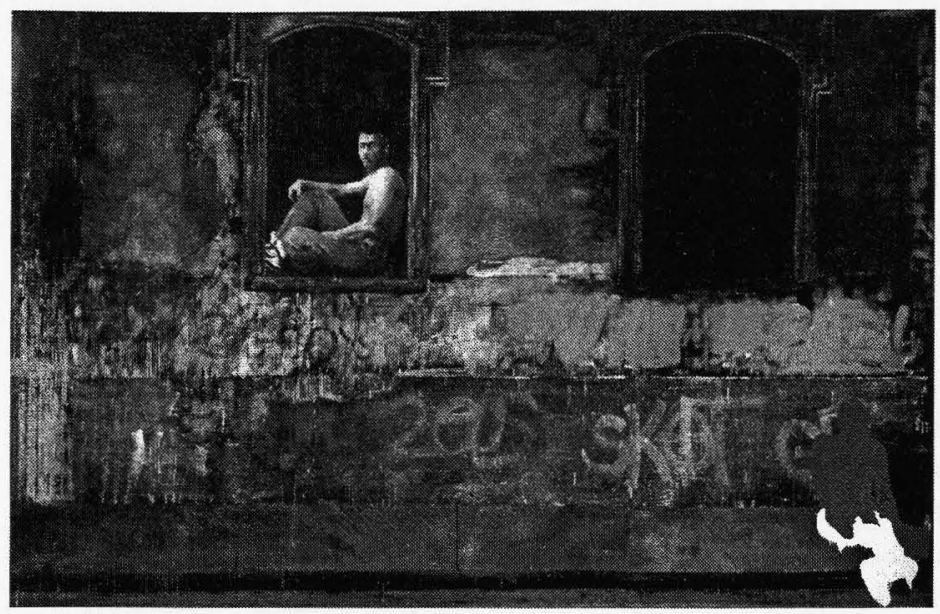

Figure 6: Attila Richard Lukacs, Everybody Wants the Same Thing, artist's collection. 


\section{4 / Savoy}

homosocial desire is constructed in terms of nationalist ambitions. These paintings recognize that desire between men is praiseworthy only when merged in nationalist fraternity, yet their collective intervention is to bring that desire to the surface in an economy of erotic signs. The erotic spectacle of the male body at work has a long history of national, and capitalist, exploitation: I think in particular of Ford Madox Brown's Work, as well as such American icons as the Chrysler Building and the frieze on the ceiling of its lobby, a triangular construction that culminates in a male torso wielding a wrench. To read Lukacs, though, I have to return to David.

At the outset of the Napoleonic campaign, David celebrated a mode of homosocial bonding that Richard Dellamora identifies as "Dorianism," the institution of pederasty as it existed in the army of ancient Sparta - the practice of love and friendship between an adult male citizen/soldier and one preparing to achieve the same status. David's Leonidas at Thermopylae provides a paradigmatic example of the aesthetic inscription of Spartan pederasty within the rhetoric of the nation-state in crisis. The evident homoeroticism of David's painting provides at once a demonstration and an analysis of the inscription of desire in the public order. The look pertains to male homosocial culture, by which the visual address fixes in place the idealized figure of Leonidas, the king of Sparta killed by the Persians at Thermopylae in $480 \mathrm{BC}$. If the look inscribes male homosocial relations of power, the process of inscription is figured in literal fashion in the soldier at the upper left who incises into the wall the epitaph "Passerby, go tell Sparta that her children have died for her." As Dellamora concludes, "the implicit apocalyptic narrative of the painting, the setting at Thermopylae where these men are about to be sacrificed, endows devotion with the sublime value of dying for the sake of civilization itself' (49).

I do not claim that Lukacs invokes Leonidas at Thermopylae in any direct way, although the troping of David's Oath of the Horatii in Glamour Crew may indeed set in motion a spiral of connotative play that, once started, is difficult to restrain. I do argue, however, that Lukacs's work intervenes in the homosocial economy as envisioned by David. In David's version of Dorianism - itself, perhaps, suspended between mourning the collapse of the republic and celebrating the rise of empire - the homoerotic is the ground that must be overwritten, overdetermined by the nationalist imperative in 
order to render it usable. In the politically queer moment of Lukacs's apocalypse, the separation of the homoerotic from the homosocial is contested, deconstructed: the cultural sites of most virulent homophobia are reconfigured under the signifying economy of the 'always already.' It is this recurring allegorical import that positions Lukacs at the end, on the brink of a secular apocalypse which is, queerly (that is, uncannily) retrospective and proleptic: the sign of his belatedness is his ironic, campy reconfiguration of male iconography, a sign that may exhaust itself in the ironic pose without hope that is Tomorrow and Tomorrow and Tomorrow. Allegories promise the apocalypse of unveiling, the revelation of a new order, but that promise cannot be kept by the allegorical mode, trapped as it is within the abbatoir of the signifier and its long, long history. Finally, the emotion that emanates from Lukacs's multiple ironies is, queerly, not a delight in virtuosity but what Bryson calls "an unfocussed melancholy" (38): Lukacs knows - as the campy queen, the ironist always knows - that his work comes at the end, that his troping and reconfiguration of tradition entail a termination that is necessary, but sorrowful. And what of Lukacs himself? At the opening of this show in Montreal, he announced his plans to relocate to New York, and his discourse, characteristically, serves as a sort of motto for Queer Theory and as the sign of postmodern historicity: "I'm sick of being Euro-trash," he says. "I just want to be trash" (Bell 61).

\section{Works Cited}

Bell, Celina. "Skinhead Esthetics." Maclean's 28 Feb. 1994: 61. Bersani, Leo and Ulysse Dutoit. Caravaggio. London: British Film Institute, 1999.

Brookner, Anita. Jacques-Louis David. London: Chatto and Windus, 1980.

Bryson, Norman. Tradition and Desire: From David to Delacroix. Cambridge: Cambridge University Press, 1984.

Defraeye, Piet. "Performances of Masculinity in Attila Richard Lukacs's E-Werk. Queering the Canon: Defying Sights in German Literature and Culture. Ed. Christoph Lorey and John L. Plews. Columbia, SC: Camden, 1998. 420-33.

Dellamora, Richard. Apocalyptic Overtures: Sexual Politics and the Sense of an Ending. New Brunswick, NJ: Rutgers University 
Press, 1994.

Hanson, Ellis. Letter. "Looking Backward, Looking Forward: MLA Members Speak.” PMLA 115 (2000): 2071-72.

Headlam, Bruce. "Attila Up Against the Wall." Saturday Night Dec. 1994: $53-59,84-88$.

Isherwood, Christopher. "Mr. Lancaster." The Faber Book of Gay Short Fiction. Ed. Edmund White. London: Faber, 1991. 89135.

Jarman, Derek, dir. Caravaggio. London: British Film Institute and Channel Four Television, 1986.

Johnson, Ken. "Attila Richard Lukacs at 49th Parallel." Art in America Sept. 1989: 204.

Mays, John Bentley. "Attila Richard Lukacs.” Public Lecture. The Nickle Arts Museum, University of Calgary. 22 Sept. 1995.

—. "Male Body Supplants Feminist Concerns in Art of the '90s." The Globe and Mail 17 Mar. 1990: C15.

-. "Skinhead Paintings Transcend the Erotic." The Globe and Mail 8 July 1989.

Meyers, Moe, ed. The Politics and Poetics of Camp. New York: Routledge, 1994.

O'Pray, Michael. Derek Jarman: Dreams of England. London: British Film Institute, 1996.

Pater, Walter. Studies in the History of the Renaissance. Ed. Donald

L. Hill. Berkeley: University of California Press, 1980.

Savoy, Eric. “The Signifying Rabbit." Narrative 3 (1995): 189-209. Sokolowski, Thomas W. Preface. Patriotism/Leadership/Discipline: An Exhibition Catalogue. Vancouver: Diane Farris Gallery, 1990. 